\title{
FORMATION OF COMMUNICATION SKILLS IN THE PROCESS \\ OF LEARNING A FOREIGN LANGUAGE BY THE FUTURE EXPERTS OF HOSPITALITY INDUSTRY
}

\author{
ФОРМУВАННЯ КОМУНІКАТИВНИХ НАВИЧОК \\ У ПРОЦЕСІ ОВОЛОДІННЯ ІНОЗЕМНОЮ МОВОЮ \\ МАЙБУТНІМИ ФАХІВЦЯМИ ІНДУСТРІЇ ГОСТИННОСТІ
}

The article is dedicated to the study of formation and development of the communication skills in foreign language (English) that will culminate in greater opportunities in professional life of the future hospitality industry experts. The most demanded in the period of formation of inter-state integration are the highly qualified experts in hospitality industry with the knowledge of foreign languages and, thus, are able to cooperate with foreign partners, make independent decisions in real situations, see the prospects and plan the strategy and tactics of the industry.

The analysis of the research devoted to the study of communication skills and ways of their formation in the process of training the future experts of hospitality industry indicates at the complexity, multidimensionality and insufficient research of this problem.

Having learned different interpretations of the term «communication» the following working definition has been offered: communication - is the process by which information is exchanged between individuals. To succeed in this process one must acquire, develop and demonstrate communication skills.

Not to confuse the two terms "skills" and "abilities" a detailed explanation of these two concepts has been made. In very basic terms, abilities are natural or inbuilt whilst skills are learned behaviours. If abilities are the willingness for conscious and accurate actions, skills are the automated link of this activity. Consequently, skills are automated abilities.

The European Reference Framework claims that to act as a speaker, writer, listener or reader, the learner must be able to carry out a sequence of skilled actions (cognitive, linguistic, phonetic, semantic, visual, manual etc.) which can be defined as the communication skills. Communication skills are essential for the successful future career of any student.

The communication functions are seen as the integral part of the process of communication skills formation which in our research are relevant to those of the career in hospitality industry: contact-making, informative, stimulating, coordinating, understanding, emotional, establishing relationships, influencing, value-motivational.

Various reasons for gaining communication skills are singled out. Thus, a great role in the training process is played by a teacher.

УДК 378.147:81'273

DOI https://doi.org/10.32843/2663-60852019-18-1-34

\section{Zhumbei M.M.}

PhD (Pedagogical Sciences)

Assistant Professor

Department of Foreign Languages

and Country Studies

Faculty of Tourism

Vasyl Stephanyk Precarpathian

National University
Стаття присвячена вивченню фрормування та розвитку навичок спілкування іноземною мовою (а саме англійською) майбутніх фрахівців сорери гостинності, що відкриє для них більші можливості у професійному житті. Найбільш затребуваними у період становлення міждержавної інтеграції є висококваліфріковані експерти індустрії гостинності, які володіють іноземними мовами i, таким чином, здатні співпрацювати з іноземними партнерами, приймати самостійні рішення у реальних ситуаціях, бачити перспективи та планувати стратегію і тактику розвитку галузі.

Аналіз праць, присвячених дослідженню комунікативних навичок і шляхів їх фрормування у майбутніх орахівців індустрії гостинності, свідчить про багатоаспектність, складність і недостатню дослідженість проблеми. Ознайомившись із різними тлумаченями терміна «спілкування» або «комунікація», ми запропонували таке робоче визначення: комунікація - це процес, за допомогою якого здійснюється обмін інформацією між індивідами. Щоб досягти успіху в цьому процесі, потрібно набувати, розвивати та демонструвати комунікативні навички.

Для встановлення чіткої різниці між термінами «навички» й «уміння» було зроблено детальне пояснення цих двох понять. Уміння $\epsilon$ природні або вбудовані, тоді як навичок набувають. Якщо уміння - це готовність до усвідомлених і точних дій, то навички - це автоматизована ланка цієї діяльності. Відтак навички - че автоматизовані уміння. у Загальноєвропейських Рекомендаціях із мовної освіти йдеться про те, що, аби висту пати мовцем, слухачем, читачем і вміти вдало висловлюватися письмово, студент повинен бути у змозі здійснити послідовність кваліфрікованих дій (когнітивних, лінгвістичних, фонетичних, семантичних і т. д.), які можна визначити як комунікативні навички. Навички спілкування є важливими для успішної майбутньої кар'єри будь-якого студента. Комунікативні фуункиіі розглядаються як невід'ємна частина процесу формування навичок спілкування, які в нашому дослідженні стосуються комунікативних фуункцій у кар'єрі в індустрії гостинності, а саме: налагодження контактів, інформативність, стимулювання, координація, розуміння, емоційність, встановлення стосунків, а також функиіі впливу і ціннісно-мотиваційного характеру. Виокремлено різні причини набуття комунікативних навичок. Таким чином, велику роль у навчальному процесі відіграє педагог. Для успішного формуванння та розвитку комунікативних навичок у фрахівців індустрії гостинності було розроблено та впроваджено у педагогічний процес новий ефективний навчально-методичний посібнuк «A Guide to Hotel Etiquette: Manners and Conversations». Праця присвячена проблемі готельного етикету, манерам і правильній 
поведінці у готелі, у супроводі профресійних комунікацій, які є спрямовані на формування навичок спілкування англійською мовою як іноземною.
Ключові слова: спілкування, комунікативна компетенція, комунікативні уміння, комунікативні навички, педагогічні умови, срахіви сорери гостинності.
Introduction. The new paradigm of development of the Ukrainian education actualizes the problem of formation of highly qualified future experts of hospitality industry who are expected to possess the communicative competency which is based on the communication skills.

The success of the future expert's business in general and social life depends on the ability to communicate effectively with the customers. Actually, one's personality, intelligence and potentials can be detected through the ways of expressing oneself. Professional communication becomes an instrument for success which brings about the importance of learning effective communication skills in order to expand potential for success both in business and personal relationships. Even in sending messages or emails, receiving or giving telephone calls, expressing oneself in different professional situations, theway of communication affects the kind of respond one gets.

Communication in foreign languages is one of the key competencies defined by the European Reference Framework (1986). It consists in the ability to understand spoken messages, to initiate, sustain and conclude conversations and to read, understand and produce texts appropriate to one's individual needs. A positive attitude involves the appreciation of cultural diversity and an interest in and curiosity about languages and intercultural communication [1].

Despite the fact that the problem of formation of the future hospitality industry experts' communication skills has found its partial coverage in certain scientific works, some aspects of this problem remain in sufficiently studied.

Objective. The article is dedicated tothe importance of forming communication skills in the process of learning a foreign language (English) that will culminate in greater opportunities in professional life of the future hospitality industry experts.

Methodology. The research is relied on the following methods: theoretical (analysis of scholarly work in pedagogy, linguistics and area studies regarding methodological approaches to teaching English as a foreign language), empirical (modelling real-world communication scenarios), and practical (the development of conversational language skills for the students - future hospitality industry experts).

Literature Review. The problem of formation of communication skills and its impact on the professional activity in leisure and tourism industry have been studied by J. Davies, T. (Ying) Lu, M. Casado, M. Yasmin, H. Dehtiariova, L. Rudenko; communication competence for health professions - by D. Dickson, O. Hargie, N. Morrow, V. Jenkins, L. Fallowfield; for journalists - by J. Newhagen, M. Levy, D. Urycki,
S. Wearden, M. Brokato, P. Furr, N. Shydei, S. Horton, V. Kostyuk; for economists - by R. Mardanshina, N. Zadorozhna, L. Harnaha; and communication skills for pedagogues - by L. Savenkova, N. Tarasevych, K. Kasiarum, S. Kleipoedszus, D. Burton, R. Akhmadulina, A. Csikosova.

The analysis of the research devoted to the study of communication skills and ways of their formation in the process of training the future experts of hospitality industry indicates at the complexity, multidimensionality and insufficient research of this problem.

Problem Setting. Modern conditions of the development of education emphasize that learning a foreign language is an integral part of the professional training of students. Therefore, taking into consideration the prospect of the Ukrainian education to integrate into the European community, precisely the expert who speaks at least one foreign language has the formed skills of intercultural communication, recognizes and respects differences in native and foreign cultures, can easily adapt to the multicultural environment and realize his/her professional and personal potential.

The most demanded in the period of formation of inter-state integration are the highly qualified experts in hospitality industry with the knowledge of foreign languages and, thus, are able to cooperate with foreign partners, make independent decisions in real situations, see the prospects and plan the strategy and tactics of the industry. The important qualities of the hospitality industry experts are communicativeness, ingenuity, creativity, ability to engage in dialogue with partners by means of following the norms of cultural, business and linguistic ethics. Therefore, the problem of development of foreign language competency is becoming of particular significance in the process of training the future hospitality industry experts. Knowledge of a foreign language is a realnecessity and a must for their successful future career.

Discussion. The term "communication" can be defined as a process of exchanging information, from the person giving the information through verbal and non-verbal methods, to the person receiving the information. The most common method of communication is verbal, using a specific language where it is a two-way process, with feedback on the message received. Communication also involves the exchange of ideas, opinions and information with a specific objective [2]

Merriam Webster Dictionary explains the term "communication" as the "act or process of using words, sounds, signs or behaviours to express or exchange information or to express your ideas, thoughts, feelings, etc., to someone else"[3]. 
Communication is seen as the process of transmitting information and common understanding from one person to another (Keyton, 2011) [4].

Summing up the given definitions we state that communication is the process by which information is exchanged between individuals. To succeed in this process one must acquire, develop and demonstrate communication skills.

To make a profound research of communication skills we must first stress on the difference between the two notions: abilities and skills. In very basic terms, abilities are natural or inbuilt whilst skills are learned behaviours.Ability is knowledge in action, knowledge-based readiness of a person to perform a particular type of activity. Along with the abilities, skills are the form of expressing the experience of performing human activity. If abilities are the willingness for conscious and accurate actions, skills are the automated link of this activity. Consequently, skills are automated abilities [5].

Among the communicative abilities, the Russian psychologist A. Leontiev distinguished two main groups: 1) the group related to the ability to use personal communicative characteristics in communication; 2) the group related to the command of the technique of communication and contact [6]. Thus, these two groups of communicative abilities unite the whole range of the personality characteristics of a hospitality industry expert (and his/her peculiar skills) that guarantee their successful communicative process. For example, the ability to control his/ her behaviour in dealing with the hotel guests, a set of perceptual abilities related to the understanding of customers, taking into account the characteristics of another individual; ability to establish, maintain contact, change its depth, go into and out of it, hand and capture the communication initiative; the ability to build a speech optimally from a psychological point of view.

According to the content and sphere of activity the abilities are divided into two types: general and special. To the general ones we refer the abilities of the future expert which are demonstrated in his/ her professional activity: ability to study, mental ability, ability to work. They provide some productivity in learning, rely on general skills to realize, plan and organize corresponding tasks, master new techniques, overcome difficulties on the way to meeting the goal.The special abilities, which are distinguished in specific spheres of activity, researchers categorize as the ability to practical activity: constructive and technical, organizational and managerial, pedagogical, entrepreneurial, etc. [7]. The general and special abilities can be successfully introduced into practice by means of communication abilities. They imply interaction with people; provide opportunity to get in contact, cause people's positive attitude towards themselves.
The European Reference Framework claims the communicative language processes are based on speaking, writing, listening and reading skills. To act as a speaker, writer, listener or reader, the learner must be able to carry out a sequence of skilled actions.

To speak, the learner must be able to:planand organisea message (cognitive skills); formulatea linguistic utterance (linguistic skills); articulate the utterance (phonetic skills). To write, the learner must be able to: organise and formulate the message (cognitive and linguistic skills); hand-writeor type the text (manual skills) or otherwise transfer the text to writing. To listen, the learner must be able to: perceive the utterance (auditory phonetic skills); identify the linguistic message (linguistic skills); understand the message (semantic skills); interpret the message (cognitive skills). To read, the reader must be able to: perceive the written text (visual skills); recognise the script (orthographic skills); identify the message (linguistic skills); understand the message (semantic skills); interpret the message (cognitive skills) [1].

Thus, having analyzed these skilled actions we can define them as the communication skills. Communication skills are essential for the successful future career of any student.

Communication as a process implements the functions of learning, education and development, which in turn are integral functions of communication. At the same time, psychologists distinguish the following communication functions, which in our research are relevant to the career in hospitality industry as well:

- contact - making a connection between partners as a state of readiness to receive and send messages and support, interconnection and cooperation;

- informative - exchange of messages, thoughts, ideas, decisions;

- stimulating - encouraging a communication or training partner, directing his/her activity to perform certain actions;

- coordinating - mutual agreement of actions for organization of joint activities;

- understanding - adequate perception of the essence of messages and intentions, attitudes, mutual understanding of states, experiences;

- emotional - conscious or unconscious exchange of emotions;

- establishing relationships - realization of one's place in the system of business, interpersonal and other connections of the social community;

- influencing - change of the partner's behaviour, value-motivational states (intentions, thoughts, decisions, ideas, needs) [8, p. 4-5].

There are certain pedagogical conditions required to create and maintain lasting, meaningful, and productive relationships through communication. For the communication in different situations in hospitality industry to be effective the hotel expert should enhance the capacity to listen, focus on the other per- 
son instead of oneself, thoroughly understand, wait for answers to questions to be fully expressed before thoughtfully responding or forming the next question.

We should stress on the importance of minding the metaskills. The word "meta" means "most effective tactics available", which combined with the word "skill' we understand as the way of being, a stance or energetic field brought to a conversation [9]. By mindfully choosing a metaskill such as sympathy, curiosity or humor (when appropriate) the condition for a more thoughtful and productive conversation is created.

Another condition for effective communication is being open to different perspectives. Seeing an issue from someone else's perspective is crucial when a problem needs to be solved. When the employers are willing to do this, clients feel heard and understood.

Summing up the above mentioned conditions of the effective conversations we can make a conclusion that without them certain conflicts, misunderstandings, and mistrust may occur.It is essential to create these conditions in a student'spersonality and model these behaviours for others to follow [10].

There are various reasons why communication skills are important for students. Communication skills help students in their study, career development, job interview, workplace, and social networking.

Reasons for gaining communication skills:

1. Communication skills help to learn more from teachers. Students need practical and deeper knowledge about the subject they are learning. Communication skills help them to listen, understand the point of view of teachers in the class. After listening and understanding what teachers are speaking about students can ask questions with confidence in order to get more knowledge.

2. Friendly teachers relieve stress while studying process. When there is atmosphere of respect, positive attitutude and sincere communication in classit enhances the ability to understand and share the feelings and emotions of each other. Communication skills build a strong friendly relationship.

3. Teamwork and collaborative effort in solving problems with other team members are an example of effective communication at work which increases productivity in the future. Effective communication improves the chances to be promoted and respected by others. In the future students will communicate with clients by texting, audio and video conferencing at work. If they are not effective in emails, dialogueing, and social engagement it will negatively influence their career progress. So, listening, writing and verbal communication while learning a foreign language plays a positive role in students' personal and career development.

4. Communication skills develop future experts' professionalism. Hospitality industry students in the future will need to communicate effectively with customers. They need politeness, friendliness, pro- fessionalism in their speaking and attitude while interacting with customers. Therefore, thinking, understanding and analyzis of the situation before speaking are of great significance.

5. While communicating, listening, expressing thoughts and understanding each other the presence of mind is improved. The focus lies on the listener which enhances the brain power and memory. Students need brainpower and good memory to become successful inachieving their aim. The usage of communication skills increases their attention and they are ready to act because of the presence of mind. The presence of mind improves their vocabulary, communication skills and memory. Every student wants to become a real professional in his/her activity which becomes possible by usage of effective communication [11].

Interpreting the above mentioned reasons of gaining communication skills ultimately leads us to the conclusion that good communication skills are a proof of a well-educated person.

For successful formation and development of the future hospitality industry experts' communication skills on the basis of the Faculty of Tourism, Vasyl Stefanyk Precarpathian National University a new and effective training manual "A Guide to Hotel Etiquette: Manners and Conversations" was developed and introduced in pedagogical process. The manual is dedicated to the problem of hotel etiquette, good manners and correct behaviour supported by conversations aimed at formation of the communication skills in English as a foreign language.

The objective of the given manual is to equip students with the ability to perform their professional activity with the foreign language competency; to develop interpersonal relationships in professional sphere; to master the technology of constructive dialogue; to form the ability to speak and to listen; to establish feedback in the communication process; to adjust to a partner through non-verbal communication; to develop skills to keep in mind several things at a time; to act while conversation with a quick reaction; to adapteasily to the interlocutor.

As a result of mastering the course "A Guide to Hotel Etiquette: Manners and Conversations" the future hospitality industry experts are supposed to possess the knowledge of:

- maintaining attention to the presented information;

- effective cooperation in pair and group work;

- rapid and frequent active use of the material learnt;

- one's own strengths and weaknesses as a learner;

- identification of one's own needs and goals in the future profession.

The training manual is characterized by the practical aspect of the tasks offered. As far as it consists 
of the texts for reading and comprehension, questions for discussion, a set of tests, dialogues for roleplaying, idioms for learning and active usage, etc., the book is aimed at the development of the foreign communication skills of the future hospitality industry experts helping them to improve not only their professional competency but to be able to have positive impact on people, construct business communication, introduce themselves as competitive experts working for the prosperous companies.

The manual offers the best examples of possible conversations in a hotel between the workers and guests. The situations are as follows: making a reservation, cancelling a reservation, checking-in, checking-out, ordering room service, dealing with complaints, asking for a taxi, asking for restaurant advice, storing luggage for a few hours, etc. The selection of such topics is determined by the real-life needs of the future hospitality industry experts.

The work with professional texts promotes the development of students' independence in search and acquisition of special knowledge, the ability to use them for summarizing, synthesizing and analyzing the information received for further practical introduction into the system of future professional activity.

The material presented in the manualis adjusted according to the communication skills needed by students to successfully manage the real-life situations. The communication skills are considered to be formed in the classroom or individually.

At the lessons of English as a foreign language the learners must feel confident to make presentations and speeches. For this they develop expressive skills which are used to introduce in life emotions, thoughts and expressions, thus, sending their point successfully to the listener. To develop expressive skills, students need to learn how to get the full attention of the listeners. Learners should be taught how to show the interlocutor respect when this person is speaking. Such etiquette will become a part of conversation in every sphere of life, both professional and personal [12].

We emphasize the importance of group activities at the lessons of foreign languages for the effective formation of communication skills. Students must complete assignments in equally divided groups. The interaction among the students will result successfully if the groups are continuously changed. Therefore, it is important to introduce active forms and methods of studying into the educational process in order to obtain profound professional communication skills.

Conclusion. To sum up, we can state that the formation of communication skills of the future hospitality industry experts is successfully realized in the process of learrning a foreign language. Consequently, it's crucial to create the conditions for their development and professional improvement.

Further research will relate to the problems and main directions of the formation of the hospitality industry experts' communication skills.

\section{REFERENCES:}

1. The Common European Framework of Reference for Languages: Learning, Teaching, Assessment. Strasbourg, 1986. URL: https://www.google.com/ url? sa $=t \& r c t=j \& q=\& e s r c=s \&$ source $=$ web $\& c d=6 \& c a d=r-$ ja\&uact=8\&ved=2ahUKEwihxaKIwojlAhVLxMQBHabEAhAQFjAFegQIBBAC\&/ (last access 30.09.2019).

2. Iksan, Z.H., Zakaria, E., Meerah, T.S.M., Osman, K., Lian, D.K.C., Mahmud, S.N.D., Krish, P. (2012). Communication skills among university students. Procedia - Social and Behavioral Sciences, 59. P. 71-76.

3. Merriam-Webster's collegiate dictionary. (1997). Springfield, MA: Merriam-Webster Incorporated. P. 608.

4. Keyton, J. Communication and Organizational Culture: A Key to Understanding Work Experiences, Sage Publishing Inc., New York, 2011.

5. Малафіїк І.В. Дидактика : навчальний посібник. Київ : Кондор, 2009. 406 с.

6. Леонтьев А.Н. Деятельность. Сознание. Личность. Москва : Политиздат, 1975. 304с.

7. Поняття здібностей та їхній розвиток. URL: http://pidruchniki.com/00000000/psihologiya/zdibnosti (last access 11.09.2019).

8. Рибалка В.В. Психологія праці особистості : навчально-методичний посібник. Київ - Кременчук : ПП Щербатих, 2006. 76 с.

9. Macmillan Dictionary. URL: https://www.macmillandictionary.com/dictionary/british/meta_1 (last access 16.10.2019).

10. Conditions Necessary for Effective Communication. URL: http:milyrogers.com/3-conditions-necessary-for-effective-communication (last access 13.10.2019).

11. Importance of communication skills for students. URL: http://www.klientsolutech.com/importance-of-communication-skills-for-students (last access 25.10.20019).

12.Zhumbei M.M. A Guide to Hotel Etiquette: Manners and Conversations : навчально-методичний посібник. Івано-Франківськ : Світ Друку, 2019. 72 с. 